No. 2

\title{
JOURNAL
}

\section{OF THE}

\section{ROYAL ASIATIC SOCIETY}

\author{
OF GREAT BRITAIN \& IRELAND
}

PUBLISHED BY THE ROYAL ASIATIC SOCIETY OF

GREAT BRITAIN \& IRELAND, WITH WHICH IS INCORPORATED

THE SOCIETY OF BIBLICAL ARCHÆOLOGY 


\section{CONTENTS}

ZAMAN, MUHAMmad QASIM: The relevance of religion and the response to it: a study of religious perceptions in early Islam.

GOODWIN, RoBert E.: Dākșinyya and Rasa in the Vikramorvaśiya ........ 265

FrYKenBeRg, ROBERT ERIC: The myth of English as a "colonialist" imposition upon India : a reappraisal with special reference to South India

Atwell, William S.: Ming observers of Ming decline: some Chinese views on the "seventeenth century crisis" in comparative perspective...

Ballhatchet, Helen: Confucianism and Christianity in Meiji Japan : the case of Kozaki Hiromichi.

GANDY, CHRISTOPHER : Clio with one eye : a new book on the Armenians in Ottoman Turkey

MARRISON, G. E.: Balinese manuscripts in the Library of the University of Leiden and other collections in the Netherlands: a review article ..........

APPLEYARD, David: The last two letters of Emperor Tewodros II of Ethiopia (April 11th and 12th 1868)-corrigenda.

ReVIEws of Books (see Annual Index) .................................................. 388

OTHER BOOKS RECEIVED FOR REVIEW ................................................. 480

MEETINGS AND LECTURES OF THE SOCIETY .......................................... 482

ANNIVERSARY MEETING................................................................... 484

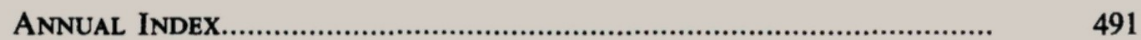


THE JOURNAL

OF

THE ROYAL ASIATIC SOCIETY 


\section{JOURNAL}

\section{OF THE}

\section{ROYAL ASIATIC SOCIETY}

OF GREAT BRITAIN \& IRELAND

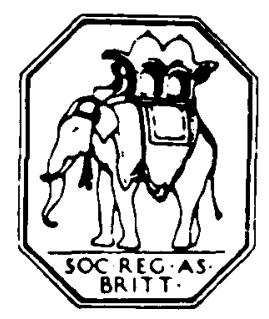

PUBLISHED BY THE ROYAL ASIATIC SOCIETY OF GREAT BRITAIN \& IRELAND, WITH WHICH IS INCORPORATED THE SOCIETY OF BIBLICAL ARCHÆOLOGY

60 QUEEN'S GARDENS, LONDON W2 3AF 


\title{
Patron \\ HER MOST EXCELLENT MAJESTY THE QUEEN
}

Vice-patron

HIS ROYAL HIGHNESS THE PRINCE OF WALES

1976 Professor Sir Harold Bailey, Fra

\section{COUNCIL OF MANAGEMENT FOR 1988-89}

1988 Mr. F. F. Steele, OBe

President

Director

1986 DR. D. J. Duncanson, obe

Vice-Presidents

1987 Mr. G. A. Calver

1987 Professor W. Watson, CBe, fBa

1988 Professor SIR Cyril PhILIPS

1988 DR. L. L. WARE, OBE

1988 MR. P. H. Collin (Hon. Treasurer)

Honorary Officers

1988 Professor A. D. H. Bivar, fSA (Hon. Secretary)

1988 DR. D. O. MORGAN (Hon. Editor)

Ordinary Members of Council

1988 Professor K. A. Ballhatchet

1988 Mr. A. S. BENNELL

1988 MR. P. T. DENWOOD

1987 DR. A. GAUR

1988 Miss E. V. Gibson

1988 MR. W. G. D. GUNN, OBE

1985 MR. R. V. HEAD

1988 MR. J. R. KNOX

1985 Miss M. MEDLEY

1985 MR. R. H. PINDER-WILSON

1987 DR A. POWELL

1988 Mr. J. B. SELWYN

1988 MR. R. W. SKELTON

1985 DR. G. R. TIBbETTS

\author{
Secretary \\ 1988 Miss L. Collins \\ Librarian \\ 1987 MR. F. G. GoODWIN \\ 60 QueEN's GaRdeNS, LONDON W2 3AF \\ (Tel: 01-742 4741/2) \\ Honorary Solicitors \\ MESSRS. WOODROFFES
}




\section{TABLE OF CONTENTS 1988}

NOTES.

ARTICLES.

$7-164,265-387$

REVIEWS OF BOOKS. 165,388

OTHER BOOKS RECEIVED FOR REVIEW 260,480

MEetings AND Lectures of THE SOCIETY

INDEX

The Society's Accounts and List of Fellows will be published separately. 


\title{
PUBLICATIONS COMMITTEE
}

\author{
Mr. F. F. Steele, OBE (Chairman) \\ Dr. D. O. Morgan (Editor) \\ Professor A. D. H. Bivar, FSA \\ Mr. P. H. Collin \\ Dr. D. J. Duncanson, OBE \\ Miss E. V. Gibson \\ Mr. F. G. Goodwin \\ Dr. A. K. Irvine \\ Professor Sir Cyril Philips \\ Mr. J. B. Selwyn
}

Assistant Editor. Mrs. L. Wright

\section{MAJOR BARWIS-HOLLIDAY AWARD FOR FAR EASTERN STUDIES (1989)}

An annual award has been instituted for the best paper submitted to the Society on an East Asian subject, based on the anthropology, art, ethnology, history, literature or religion of China, Japan, the Soviet Far East, Korea, Taiwan and Hong Kong. Award-winning entries will be published in the Society's Journal. Within the usual format no rigid limit is imposed on the length of the contributions submitted, but it should be understood that the most suitable length is about 6,000 words.

The manuscript should be typed in double spacing on sheets of A4-size, leaving a margin of at least $30 \mathrm{~mm}$ on the left-hand side, and the sheets should be numbered consecutively at the top right-hand corner. Notes should be numbered consecutively throughout the article, and typed on a separate sheet or sheets at the end. Entries for the award should be submitted by 31 December 1988, and addressed to the Secretary, Royal Asiatic Society, 60 Queen's Gardens, London W2 3AF, England.

The prize for 1988 was awarded to Professor W. S. Atwell for his paper, "Ming observers of Ming decline: some Chinese views on the 'seventeenth century crisis' in comparative perspective" published below, pages 316-348. 


\section{CORPORATE SUBSCRIBERS}

The Council is grateful to the Corporate Subscribers to the Society, whose generosity sustains its work, including the publication of the Journal.

The Hongkong and Shanghai Banking Corporation

The British Bank of the Middle East

Grindlays Bank Plc

Pauling \& Co. Plc

Matheson \& Co. Plc

Lloyds Bank Plc

Shell International

Steel Brothers Plc

Sotheby Parke Bernet \& Co.

John Swire and Sons Ltd

(C) Royal Asiatic Society 1988

UK ISSN 0035-869X 